\title{
Targeted Therapy: Any Place in the Management of Chronic Adenotonsilitis
}

\author{
Omar Ramadan* \\ Department of ENT, USA \\ Submission: January 30, 2017; Published: February 07, 2017 \\ *Corresponding author: Omar Ramadan, Independent researcher, ENT registrar, Paterson NJ, USA
}

\section{Opinion}

The mucosal layer of oral cavity and upper respiratory tract has a major role in protecting the human body from infectious agents. Waldeyer's ring including tonsils and adenoid located at the junction of both the digestive and respiratory tracts provides also an immunological protaction [1]. New immune-biological tests have helped in recognition of tonsillar cells responsible for the immunity reactions. Recurrent or chronicadenotonsillar infections mainly occur in children and also may affect healthy subjects. Local dysfunction of the rhino-oro-pharyngeal epithelium of the host is the main cause of this entity; also some cases may be triggered by the systemic immunological deficiencies. This leads to inappropriate immunity reaction towards the infectious microorganisms that are characterized by recurrent adenotonsilitis [2].

Multiple articles have reported that $\mathrm{T}$ lymphocytes located in the tonsillar crypt epithelium may produce pro-inflammatory Th1 type cytokines such: IL-2, IFN- $\gamma$, TNF- $\alpha$ and antiinflammatory Th2 type cytokines: IL-4, IL-5, IL-6, and IL-13 after antigenic stimulation. Production of Th1 type cytokines is usually the dominant. In chronic tonsillitis production of cytokines starts withTh1-type and later on the production of Th2 type cytokines. The role of those cytokines is well understudied and heterogeneous [3]. Todorović et al. [3] studied the distribution of cells producing tumor necrosis factor $\alpha$ and interleukin 6 in patients with recurrent tonsillitis and tonsillar hypertrophy. They found that number of TNF- $\alpha$ producing cell were significantly higher in recurrent tonsillitis patients compared with tonsillar hypertrophy patients. The concentration of IFN- $\gamma$ was three times higher in recurrent tonsillitis patients than in tonsiller hypertrophy patients.

Passali et al. [4] reported that interleukin-1, interleukin-6, and TNF-a were significantly raised in all the specimens of adenotonsilltis patients studied post-operatively. KheirandishGozal et al. [5] did an in vitro study on tonsil and adenoid tissue removed post adentonsilectomy. In the study the tissue was cultured in corticosteroids and the levels of TNF $\alpha$, IL- 6 , and IL-8 were measured. The study found that tonsils and adenoids obtained from children with obstructive sleep apnoea undergoing tonsillectomy and adenoidectomy displayed increased proliferative rates and pro-inflammatory cytokine production. In addition, treatment with corticosteroids resulted in marked reductions in proliferative rates, increased cellular apoptosis and reduced cytokine release.

Sugiyami et al. [6] did a study on the influence of IL-6 on proliferation and differentiation of tonsillar lymphocytes. Tonsillar B cells were cultured in the presence of external interleukin-6, a small portion of them differentiated into plasma cells which seemed to have also IL-6 receptors on their surfaces. The number of plasma cells tended to be greater in the tonsils of children than in the tonsils of adults. Unal et al. [7] reported that serum IL-6 and IL- $1 \beta$ levels were significantly higher in chronic tonsillitis patients than the control. After tonsillectomy, IL-1 $\beta$ and IL-6 levels were significantly reduced. He suggested that IL-1 $\beta$ and IL- 6 may be the mediators which play a role in chronic tonsillitis. Desiderio et al. [8] analyzed the structural and immunological aspects of tonsils and adenoids in subjects who underwent adenotonsillectomy because of recurrent adenotonsilitis. He found that serum and tissue interleukin$1 B$ and TNF- a were higher IN the adenotonsillar specimens, whereas the IL- 6 has a moderate rising.

Esteitie et al. [9] studied the effect of fluticasone on interleukin 6 secretions from adenoid tissues. The study showed a production reduction of IL-6 in adenoid tissue obtained from children complaining of obstructive sleep apnea syndrome treated with fluticasone nasal spray. It has also been reported that the chronic tonsilitis may trigger multiple immunologic disorder such sternocostoclavicular hyperostosis, reactive arthritis, rheumatic fever, palmoplantarpustulosis, erythema nodosum, 
IgA Nephropathy, purpura nephritis and psoriasis [10]. There are a lot of controversies about the benefits of tonsillectomy in the previous immunologic disorders, but what about the using of targeted anti-inflammatory therapy in those patients, can we use this therapy also to prevent those autoimmune diseases in chronic tonsillitis patients at high risks.

Targeted anti-inflammatory therapy using anti-IL6, anti- IL4, and anti-TNF $\alpha$ may have a role in the management of chronic adenotonsilitis. It could be tried as a palliative therapy for chronic adenotonsilitis patients who are contraindicated for surgery due other Anastasia or health problems. It could be also tested as adjuvant or alternative to long-acting penicillin protective therapy for the patients of rheumatic fever.

\section{Reference}

1. Sigurdardottir SL, Thorleifsdottir RH, Valdimarsson H, Johnston A (2013) The role of the palatine tonsils in the pathogenesis and treatment of psoriasis. Br J Dermatol 168(2): 237-242.

2. Passàli D, Damiani V, Passàli GC, Passàli FM, Boccazzi A, et al. (2004) Structural and immunological characteristics of chronically inflamed adenotonsillar tissue in childhood. Clin Diagn Lab Immunol 11(6): 1154-1157.

3. Todorović MM, Zvrko EZ (2013) Immunoregulatory cytokines and chronic tonsillitis. Bosn J Basic Med Sci 13(4): 230-236.
4. Passàli D, Damiani V, Passàli GC, Passàli FM, Boccazzi A, et al. (2004) Structural and immunological characteristics of chronically inflamed adenotonsillar tissue in childhood. Clin Diagn Lab Immunol 11(6):1154-1157.

5. Kheirandish-Gozal L, Serpero LD, Dayyat E, Kim J, Goldman JL, et al. (2009) Corticosteroids suppress in vitro tonsillar proliferation in children with obstructive sleep apnoea. Eur Respir J 33(5): 1077-1084.

6. Sugiyama M, Uekawa M, Yamane $H$, Takeda $M$, Sakamoto $H$, et al. (1991) Influence of IL-6 on proliferation and differentiation of tonsillar lymphocytes and detection of IL-6 producing cells in tonsil. Acta Otolaryngol Suppl 486: 245-253.

7. Unal M, Oztürk C, Görür K (2002) Effect of tonsillectomy on serum concentrations of interleukins and TNF-alpha in patients with chronic tonsillitis. ORL J Otorhinolaryngol Relat Spec 64(4): 254-256.

8. Desiderio Passàli, Valerio Damiani, Giulio Cesare Passàli, Francesco Maria Passàli, Antonio Boccazzi, et al. (2004) Structural and Immunological Characteristics of Chronically Inflamed Adenotonsillar Tissue in Childhood. Clin Diagn Lab Immunol 11(6): 1154-1157.

9. Esteitie R, Emani J, Sharma S, Suskind DL, Baroody FM (2011) Effect of fluticasone furoate on interleukin 6 secretion from adenoid tissues in children with obstructive sleep apnea. Arch Otolaryngol Head Neck Surg 137(6): 576-582.

10. Kaneko T, Mii A, Fukui M, Nagahama K, Shimizu A, et al. (2015) IgA nephropathy and psoriatic arthritis that improved with steroid pulse therapy and mizoribine in combination with treatment for chronic tonsillitis and epipharyngitis. Intern Med 54(9): 1085-1090.

\section{Your next submission with Juniper Publishers will reach you the below assets}

- Quality Editorial service

- Swift Peer Review

- Reprints availability

- E-prints Service

- Manuscript Podcast for convenient understanding

- Global attainment for your research

- Manuscript accessibility in different formats

( Pdf, E-pub, Full Text, Audio)

- Unceasing customer service

Track the below URL for one-step submission https://juniperpublishers.com/online-submission.php 